\title{
Day of the Week Effect, Annual Returns and Volatility of Five Stock Markets in Southeast of Asia
}

\author{
Mansooreh Kazemi Lari (Corresponding author) \\ Dept. of Mathematical Science, Faculty of Science \\ Universiti Teknologi Malaysia (UTM), 81310, Johor Bahru, Johor, Malaysia \\ Tel: 60-12-665-7562Ｅ-mail: Kazemilari_m@yahoo.com
}

\begin{abstract}
Abbas Mardani
Dept. of Management, Faculty of Management and Human Resource Development, Universiti Teknologi Malaysia (UTM), 81310 Johor Bahru, Johor, Malaysia

Tel: 60-17-665-1841Ｅ-mail: abbas.mardani.2000@gmail.com
\end{abstract}

\author{
Mohsen Aghaeiboorkheili \\ Ibnu Sina institute of fundamental science studies \\ University Teknologi Malaysia, 81310 UTM Skudai, Malaysia \\ E-mail: drmohsenaghaei@yahoo.com
}

Received: December 6, 2012 Accepted: June 12, 2013 Published: June 12, 2013

doi:10.5296/ajfa.v5i1.2811 URL: http://dx.doi.org/10.5296/ajfa.v5i1.2811

\begin{abstract}
In this study, we analyze the annual returns, returns fluctuation and the day of the week effect for five stock markets in Southeast of Asia (Indonesia, Malaysia, Philippine, Singapore and Thailand) from 31, December 2007 to 31, December 2011. Non-parametric tests and parametric test are used for equality of variance returns and equality of mean returns on the daily returns of the week. Graphical representation of indexes annual changes and their correlation were explored to employ this analysis. The results indicate that all of the indexes experienced high negative changes in 2008 and after this decline, market index growth enormously. Especially Indonesia experienced the highest increase. There was generally high volatility of returns. The results of the Levene's test of the equality of standard deviations of
\end{abstract}




\section{Macrothink}

Asian Journal of Finance \& Accounting ISSN 1946-052X 2013, Vol. 5, No. 1

the returns at the 5 percent confidence level reject the Null Hypothesis that mean returns are not equal across the days of the week for all the markets except for Indonesia and Malaysia.

Keywords: Annual Returns Analysis, Day- of- the- Week effect, Volatility of Returns 


\section{Introduction}

Seasonality or calendar anomalies such as month of the year and day of the week effects has remained a topic of interest for research since a long time ago in both developed and developing countries. In stock markets, various studies have been extensively conducted and published on financial market anomalies which deal with the cross-sectional and time series patterns of world market returns using annual return data.

Seasonality in stock returns was first reported by Wachtel (1942). Rozeff and Kinney (1976) documented the January effect in New York Exchange stocks, and Brown, Keim, Kleidon, and Marsh (1983) studied the Australian stock market seasonality. Keim (1983) studied the seasonality and size effects in stock returns while Gultekin and Gultekin (1983) examined the presence of stock market seasonality in 16 industrial countries. Mills and Coutts (1995) studied the calendar effect in FTSE 100, Mid 250 and 350 indices for the period 1986 and 1992. Choudhry (2000) reported January effect on the UK and US stock returns. Chordia, Roll, and Subrahmanyam (2001) studied NYSE-listed stocks from 1988 to 1998 and found a strong day-of-the-week effect where trading activity is relatively high on Tuesdays and low on Fridays. Fountas and Segredakis (2002) studied 18 markets and reported seasonal patterns in returns. Meanwhile, Ariel (2012) has also conducted similar studies on US market indices from 1963 to 1981.

Although calendar anomalies in developed equity markets have been investigated extensively, little attention has been paid to Asian markets. Moreover, most studies of Asia anomaly focused more on seasonal or cross-sectional of stock returns. These tests are different from time series tests, which emphasize on the predictability of return rates over time (Claessens, 1995). To the best of the author's knowledge, empirical research on the day-of-the-week effect in Asian stock markets is fragmented, thus this current study attempts to fill this gap.

In this paper, we examine the characteristics of daily and annual returns and the volatility of returns of five southeast financial market indexes namely: Kuala Lumpur Composite (Malaysia); Jakarta Composite (Indonesia); Manila Composite (Philippines); Straits Times (Singapore); SET (Thailand).

\section{Literature Review}

The efficient market hypothesis (EMH) is considered one of the most debated and investigated issues in finance literatures. It states that a market is considered to be efficient if it reacts and responds quickly and accurately to all available information. Fama (1970) classified market efficiency into three forms: weak-form EMH, semi-strong form EMH, and strong form EMH. Over the last decades, however, numerous empirical studies have indicated persistent and potentially exploitable days-of-the-week patterns in both stock returns and volatility in many countries. These daily anomalies present a challenge to the EMH and have attracted much attention from economists and market practitioners. From a financial perspective, there are three important reasons for examining the daily anomalies in the markets. Firstly, the discovery of anomalous patterns in stock returns is important because of their effects on the trading strategies of investors (Berk \& Güven, 2003).

Secondly, it provides extra information for rational decision-makers to become more aware of 
variations in stock returns volatility due to the day-of-the-week effect. Rational decision-makers can also determine whether high or low returns are associated with a correspondingly high or low volatility for a given day. If investors can identify a certain pattern of volatility, it becomes easier to make investment decisions based on both projected returns and risks associated with a particular security (Kiymaz \& Berument, 2003). Thirdly, the investigation of anomalous patterns may reveal evidence about the extent of market efficiency.

\subsection{Day-of-the Week Effect}

The earliest examination of the Day-of-the-week-effect in stock returns seems to go back to the study by Cross (1973) and around the period of 1980s; French (1980), Lakonishok and Levi (1982), Gultekin and Gultekin (1983), Keim (1983), Keim and Stambaugh (1984), Rogalski (1984), Theobald and Price (1984), Harris (1986), Smirlock and Starks (1986), Jaffe and Westerfield (1989) had investigated this effect across different markets. This topic continues to be one of the most researched topics even until today, for example; Balaban (1995), Chusanachoti and Kamath (2002), Kiymaz and Berument (2003), Kohers et al. (2004), Kok and Wong (2004), Brusa et al. (2005), Cai et al. (2006), Chukwuogor-Ndu (2007), Kenourgios et al. (2008), Marrett and Worthington (2009), Anwar and Mulyadi (2009), Blau, Van Ness, and Van Ness (2009), Christophe, Ferri, and Angel (2009), Naliniprava (2010), Sutheebanjard and Premchaiswadi (2010), Worthington (2010), Faryad, Kashif, and Rana (2011), Mine and Ikram (2011), Abdullah et al. (2011), Ulussever et al. (2011) and Al-Jafari (2012) had revealed evidence of the presence of day-of-the-week effect.

On the contrary, some researchers have found no evidence for the days-of-the-week effect on stock markets. For instance, Santesmases (1986), Pena (1995), Gardeazabal and Regulez, (2003) documented on insignificant weekday effects on the Spanish stock market. Brooks and Persand (2001) also found no day-of-the-week effect in the Philippines stock market. Marashdeh (1994) and Davidson and Peker (1996) concluded that there is no day-of-the-week effect on the Malaysian stock market. Demirer and Karan (2002) studied in the Turkish stock market and did not find clear evidence of "the effect" even though they noted that Friday returns were "consistently high". Aly et al. (2004) studied the Egyptian market and showed that there was no significant difference between daily mean returns. In a study for a small offshore market of Mauritius, Agathee (2008) suggested no significant existence of the calendar effect.

\section{Research methodology}

In this section, we apply some tests to determine the day-of- the- week effect, daily returns and volatility returns. The data consist of daily closing prices excluded public holidays of the following indexes: Kuala Lumpur Composite (Malaysia) index; Jakarta Composite (Indonesia) index; Manila Composite (Philippines) index; Straits Times (Singapore) index and SET (Thailand) index for the period 2008-2012. During this period trading will be conducted Monday to Friday.

To interpret the trends of returns and depict the annual trends in the stock market movement, we use the closing index values. The logarithmic return of daily stock returns is defined as: $\ln \left(P_{t}\right)-\ln \left(P_{t-1}\right)$.

Where $P_{t}$ is a daily return of stock at time $t$. Basic statistics of return are used to find out the 


\section{Macrothink

distributions of daily returns and volatility such as standard deviations, variance, coefficient of variation, skewness and kurtosis.

Since the distributions of the returns are non normal, we use the Kruskal-Wallis one way analysis of variance which is a nonparametric method for testing equality of means (Hourvouliades, 2009). To examine the difference in the returns across the days of the week, The Kruskal-Wallis test is calculated for checking the equality on mean returns as:

$$
K=\frac{12}{N(N+1)} \sum_{i=1}^{k} \frac{R_{i}^{2}}{n_{l}}-3(n+1)
$$

Where $k$ is the number of samples; $n_{j}$ is the number of observations in $j^{\text {th }}$ sample; $N=\sum n_{j}$ is the total number of observations; $R_{j}$ is the sum of ranks in the sample when $N$ values are ranked together.

For the equality of variance across the days of the week, we employ the Levene's homogeneity test for equality of variance across the days of the week

$$
F=\left[\sum_{j=1}^{I} n_{l}\left(D_{j}-D_{j}\right]^{2} / \sum_{\mathrm{j}=1}^{1} \sum_{j=1}^{n_{i}}\left(D_{i j}-D_{j}\right)^{2}\right] \mathrm{x}\left[\frac{(N-I)}{(J-1)}\right]
$$

Where $D_{i j}=\left|R_{i j}-M_{i j}\right|, R_{i j}$ is the return for week I and weekday $\mathrm{j}$ for $j=1,2 \ldots, J$ and $J=5$.

The Bartlett's test is also employed to check the equality of variance is called homogeneity of variances that is more sensitive than Levene's test (Snedecor \& Cochran). The Bartlett's statistic is as follows:

$$
M=v\left(a \ln s^{-2}-\sum \ln s_{i}^{2}\right)
$$

Where $a$ is the number of samples, $v=$ degree of freedom, $s^{-2}-\Sigma s_{t}^{2} / a$.

When the degrees of freedom are different, above test is not used. The test criterion is as follows:

$$
\begin{gathered}
M=\left(\sum v_{i}\right) \ln \Sigma^{-2}-\sum\left(V_{i} \ln \varepsilon_{1}^{2}\right) \\
\left.c=1+\left\{\frac{1}{[3(a-1)]}\right\} \sum \frac{1}{v_{i}}-\frac{1}{\sum v_{t}}\right)
\end{gathered}
$$

Where $s_{i}^{2}$ is an estimate of the $\sigma^{2}$ from the sample $i, a=$ the number of samples, $v_{i}$ is the degree of freedom of samples $i$.

\section{Results}




\subsection{Returns Analysis of the Week}

Table 1 report the basic statistics of returns for each day of the week in total observations of 1042 to specify the distributional properties of Malaysia, Indonesia, Philippines, Singapore and Thailand. Indonesia and Malaysia have negative returns on Monday and Tuesday. Thailand has negative returns on Monday and Thursday and Philippines have negative returns on Monday and Tuesday and Friday while the Singapore has negative return all days except Wednesday.

\subsection{Volatility of Returns}

In terms of statistics in Table 1, lowest and highest returns are recorded in Jakarta Composite (Indonesia) and SET (Thailand) as a result of high volatility in these returns. The other indicators of return volatility consist of skewness, kurtosis, standard deviation, variance and coefficient of variation had also the high values. The coefficient of variation for Indonesia has a positive return while in Thailand is negative return in the same days on Thursday. However this indicator was also very high for Philippines on Friday. Moreover Malaysia has highest kurtosis and skewness on Monday. This reflects the paucity of the returns relative to their respective standard deviations. It is important to note that the daily returns for all indexes are skewed to the left except for Straits Times (Singapore) Exchange that seem to be more skewed to the right.

Malaysia and Thailand recorded the highest return on Monday, Indonesia on Wednesday, Philippine on Tuesday and Singapore on Thursday. Indonesia, Malaysia and Thailand experienced their lowest return on Monday while Philippine and Singapore experienced their lowest return on Friday. So Malaysia and Thailand recorded the highest and lowest return on Monday. The highest Standard deviation occurred on Monday for all of the stock markets. The lowest standard deviation mostly occurred on Wednesday for Malaysia, Philippine and Thailand. The daily returns exhibited greatest volatility on Monday for all of the markets except for Philippine on Thursday.

\subsection{Annual Returns Analysis}

In the period 2008 to 2012, all of the countries experienced a decline in the end of 2008. After this drop in the last of October of 2008, Indonesia, Thailand and Philippine have grown enormously: Jakarta Composite (Indonesia) by 244 percent; SET (Thailand) by 167 percent; Manila Composite (Philippines) by 156 percent while Malaysia had a steady trend by 82 percent. Singapore reached a minimum value in March of 2009 then went up by 82 percent. Table 3 shows the annual closing returns of the indexes. In Figure 1, we consider the annual returns and represent the percentage changes related to Annual Returns of Table 3.

During the period (31, December 2007 until 31, December 2011), annual returns of Indonesia increases 39.2 percent; Malaysia 6 percent; Philippine 20.7 percent; Singapore 24 percent and Thailand 19.5 percent. The markets generally declined in 2008 and gained in 2009.

The five closing index values for the period 2008-2012 applied to a regression analysis. The correlation coefficient matrix indicates the correlation among all of the indexes that 
calculated by Pearson correlation coefficient is shown in Table 4. All of pair markets have similar and positive correlation between 0.4 and 0.63 . The highest correlation 0.628 was between the Jakarta Composite (Indonesia) and the Straits Times (Singapore) Index.

\subsection{The Day of the Week Effect}

The Kruskal-Wallis test is used to examine the day of the week effect by following null hypothesis and the alternate hypothesis for each stock market.

$\mathrm{H}_{0}$ : there is equality among the days of the week returns;

$\mathrm{H}_{1}$ : there is not equality among the days of the week returns.

If the assumption reject the equality among the days of the week returns, this means that there is a difference in the returns across the days of the week and exist the presence a day-of-the-week effect on the returns that in our study accrues only in Indonesia. The results of Kruskal-Wallis test at the 5 percent level show that the Chi-square statistics values are not significant for all markets except Indonesia. In terms of what obtained in Table 5, these results support the existence the day of the week effect just Indonesia stock return in terms of the result of analysis of daily returns for the Kuala Lumpur Composite (Malaysia); Jakarta Composite (Indonesia); Manila Composite (Philippines); Straits Times (Singapore); SET (Thailand) stock markets from 2008 to 2012.

\subsection{Homoskedasticity}

The equality of the standard deviations examined by the Levene's test employed across the day of the week. As a result of Table 6, the assumptions of homoscedasticity were met in Indonesia and Malaysia.

Philippine, Thailand and Singapore have highly significant Levene's statistic (at the 5 percent level) respectively. It can be concluded that in the Indonesia and Malaysia markets, the daily return seasonalities are not accompanied by any volatility seasonality and investing on the low or high return during weekdays does not necessarily means that risk is also low or high. It is interesting to note that for Philippine that has a highly significant Levene's statistic, the highest return occurs on Wednesday, the same day that the markets experiences the lowest standard deviation. In Thailand and Singapore that have high significant Levene's statistic, the lowest return occurs on Monday when the market experiences the highest standard deviation. This observation seems compatible with the trade-off of normal risk return for higher returns as well as relationships among higher risk returns and lower risk returns.

\section{Conclusion}

This study analyzed the day-of-the-week effect, annual returns and the volatility of daily returns of five Southeast of Asia stock markets. The results of the Kruskal-Wallis test show the presence of the day of the week effect only in Indonesia and other stock returns including Malaysia, Philippine; Singapore and Thailand do not provide the existence of the daily effect.

We attempted to investigate the high volatility in daily observation of Southeast of Asia stock market. Indonesia and Thailand recorded the maximum and minimum returns. The results of 
the other indicators of return volatility had also high value of these two indexes.

Philippine, Thailand and Singapore have high significant Levene's statistic value at the 5 percent level, respectively. So, the assumptions of homoscedasticity were met in Indonesia and Malaysia.

All of five stock return indexes decreased significantly in last of 2008 then they increased between beginning of 2009 and 2012. The changes in annual closing values of the indexes indicate that in general, the markets seem to gain and lose simultaneously. However Indonesia experienced the greatest percentage increase in this period, Malaysia experienced the lowest increase between other markets. Generally, all of the stock markets in this study have grown after a decline in the last months of 2008.

The correlation coefficient matrix indicates that the correlation among all of the indexes is positive; between 0.4 and 0.6 .

\section{Acknowledgement}

The authors would like to thank of Universiti Teknologi Malaysia (UTM), also very grateful of Ministry of Higher Education of Malaysia for their sincere supports.

\section{References}

Abdullah, R., Baharuddin, N., Shamsudin, N., Mahmood, W., \& Sahudin, Z. (2011). The day of the week effect on Bursa (Bourse) Malaysia Shariah-compliant market. Interdisciplinary Journal of Research in Business, 1(4), 29-36.

Agathee, U. S. (2008). Day of the week effects: Evidence from the stock exchange of Mauritius (SEM). International Research Journal of Finance and Economics, 17, 7-14.

Al-Jafari, M. K. (2012). An Empirical Investigation of the Day-of-the-Week Effect on Stock Returns and Volatility: Evidence from Muscat Securities Market. International Journal of Economics and Finance, 4(7), p141. http://dx.doi.org/10.5539/ijef.v4n7p141

Aly, H., Mehdian, S., \& Perry, M. (2004). An analysis of day-of-the-week effects in the Egyptian stock market. International journal of business, 9(3).

Anwar, Y., \& Mulyadi, M. S. (2009). The day of the week effects in Indonesia, Singapore, and Malaysia stock market.

Ariel, R. A. (2012). High stock returns before holidays: existence and evidence on possible causes. The Journal of Finance, 45(5), 1611-1626. http://dx.doi.org/10.1111/j.1540-6261.1990.tb03731.x

Balaban, E. (1995). Day of the week effects: new evidence from an emerging stock market. Applied Economics Letters, 2(5), 139-143. http://dx.doi.org/10.1080/135048595357465

Berk, C., \& Güven, S. (2003). Stock returns and the day-of-the-week effect in Istanbul Stock Exchange. Applied Economics, 35(8), 959-971. http://dx.doi.org/10.1080/0003684032000050586 
Blau, B. M., Van Ness, B. F., \& Van Ness, R. A. (2009). Short selling and the weekend effect for NYSE securities. Financial Management, 38(3), 603-630. http://dx.doi.org/10.1111/j.1755-053X.2009.01049.x

Brooks, C., \& Persand, G. (2001). Seasonality in Southeast Asian stock markets: some new evidence on day-of-the-week effects. Applied Economics Letters, 8(3), 155-158. http://dx.doi.org/10.1080/13504850150504504

Brown, P., Keim, D. B., Kleidon, A. W., \& Marsh, T. A. (1983). Stock return seasonalities and the tax-loss selling hypothesis: analysis of the arguments and Australian evidence. Journal of Financial Economics, 12(1), 105-127. http://dx.doi.org/10.1016/0304-405X(83)90030-2

Brusa, J., Liu, P., \& Schulman, C. (2005). Weekend effect,'reverse'weekend effect, and investor trading activities. Journal of Business Finance \& Accounting, 32(7-8), 1495-1517. http://dx.doi.org/10.1111/j.0306-686X.2005.00637.x

Cai, J., Li, Y., \& Qi, Y. (2006). The day-of-the-week effect: new evidence from the Chinese $\begin{array}{llll}\text { stock market. } & \text { Chinese } & \text { 31-88. }\end{array}$ http://dx.doi.org/10.2753/CES1097-1475390206

Chordia, T., Roll, R., \& Subrahmanyam, A. (2001). Market liquidity and trading activity. The Journal of Finance, 56(2), 501-530. http://dx.doi.org/10.1111/0022-1082.00335

Choudhry, T. (2000). Day of the week effect in emerging Asian stock markets: evidence from the GARCH model. Applied Financial Economics, 10(3), 235-242. http://dx.doi.org/10.1080/096031000331653

Christophe, S. E., Ferri, M. G., \& Angel, J. J. (2009). Short selling and the weekend effect in Nasdaq stock returns. Financial Review, 44(1), 31-57. http://dx.doi.org/10.1111/j.1540-6288.2008.00209.x

Chukwuogor-Ndu, C. (2007). Day-of-the-week effect and volatility in stock returns: Evidence from East Asian financial markets. International Journal of Banking and Finance, $5(1), 7$.

Chusanachoti, J., \& Kamath, R. (2002). Market conditions, return distributions and the day-of-the-week effects in Thailand: The experience of the 1990s. American Business Review, 20(1), 6-14.

Claessens, S. (1995). The emergence of equity investment in developing countries: overview. The World Bank Economic Review, 9(1), 1-17. http://dx.doi.org/10.1093/wber/9.1.1

Cross, F. (1973). The behavior of stock prices on Fridays and Mondays. Financial Analysts Journal, 67-69. http://dx.doi.org/10.2469/faj.v29.n6.67

Davidson, S., \& Peker, A. (1996). Malaysian evidence on the robustness of the day-of-the-week effect. Capital Markets Review, 4(2), 15-29.

Demirer, R., \& Karan, M. B. (2002). An investigation of the day-of-the-week effect on stock returns in Turkey. Emerging Markets Finance \& Trade, 47-77. 
Fama, E. F. (1970). Efficient Capital Markets: A Review of Theory and Empirical Work. The Journal of Finance, 25(2), 383-417. http://dx.doi.org/10.2307/2325486

Faryad, H., Kashif, H., \& Rana, S. (2011). Day of the Week Effect and Stock Returns: Evidence from Karachi Stock Exchange-Pakistan. Far East Journal of Psychology and Business, 1(3), 25-31.

Fountas, S., \& Segredakis, K. N. (2002). Emerging stock markets return seasonalities: the January effect and the tax-loss selling hypothesis. Applied Financial Economics, 12(4), 291-299. http://dx.doi.org/10.1080/09603100010000839

French, K. R. (1980). Stock returns and the weekend effect. Journal of Financial Economics, 8(1), 55-69. http://dx.doi.org/10.1016/0304-405X(80)90021-5

Gardeazabal, J., \& Regulez, M. (2004). A factor model of seasonality in stock returns. The Quarterly Review of Economics and Finance, 44(2), 224-236. http://dx.doi.org/10.1016/S1062-9769(03)00032-2

Gibbons, M. R., \& Hess, P. (1981). Day of the week effects and asset returns. Journal of Business, 579-596. http://dx.doi.org/10.1086/296147

Gultekin, M. N., \& Gultekin, N. B. (1983). Stock market seasonality: international evidence. Journal of Financial Economics, $12(4), \quad 469-481$. http://dx.doi.org/10.1016/0304-405X(83)90044-2

Harris, L. (1986). A transaction data study of weekly and intradaily patterns in stock returns. $\begin{array}{llll}\text { Journal of Financial } & \text { Economics, } & 16(1), & 99-117 .\end{array}$ http://dx.doi.org/10.1016/0304-405X(86)90044-9

Hourvouliades, N. (2009). New Evidence for the Day-of-The-Week Effect in the Financial Crisis. Available at SSRN 1515164.

Jaffe, J., \& Westerfield, R. (1989). Is there a monthly effect in stock market returns?: Evidence from foreign countries. Journal of Banking \& Finance, 13(2), 237-244. http://dx.doi.org/10.1016/0378-4266(89)90062-9

Keim, D. B. (1983). Size-related anomalies and stock return seasonality: Further empirical evidence. Journal of Financial Economics, 12(1), 13-32. http://dx.doi.org/10.1016/0304-405X(83)90025-9

Keim, D. B., \& Stambaugh, R. F. (1984). A Further Investigation of the Weekend Effect in Stock Returns. The Journal of Finance, 39(3), 819-835. http://dx.doi.org/10.1111/j.1540-6261.1984.tb03675.x

Kenourgios, D., Samitas, A., \& Papathanasiou, S. (2008). The day of the week effect patterns on stock market return and volatility: Evidence for the Athens Stock Exchange. International Research Journal of Finance and Economics, 15(1), 78-89.

Kiymaz, H., \& Berument, H. (2003). The day of the week effect on stock market volatility and volume: International evidence. Review of Financial Economics, 12(4), 363-380. 
http://dx.doi.org/10.1016/S1058-3300(03)00038-7

Kohers, G., Kohers, N., Pandey, V., \& Kohers, T. (2004). The disappearing day-of-the-week effect in the world's largest equity markets. Applied Economics Letters, 11(3), 167-171. http://dx.doi.org/10.1080/1350485042000203797

Kok, K., \& Wong, Y. (2004). Seasonal anomalies of stocks in ASEAN equity markets. Sunway College Journal, 1, 1-11.

Lakonishok, J., \& Levi, M. (2012). Weekend effects on stock returns: a note. The Journal of Finance, 37(3), 883-889. http://dx.doi.org/10.1111/j.1540-6261.1982.tb02231.x

Marashdeh, O. (1994). Calender anomalies Evidence From Four ASIAN-PACIFIC Stock Markets. Kelola, 3(1994).

Marrett, G. J., \& Worthington, A. C. (2009). An empirical note on the holiday effect in the Australian stock market, 1996-2006. Applied Economics Letters, 16(17), 1769-1772. http://dx.doi.org/10.1080/13504850701675474

Mine, A., \& Ikram, D. (2011). Short Selling and the Day of the Week Effect for Istanbul Stock Exchange. International Research Journal of Finance and Economics, 70, 205-216.

Naliniprava, T. (2010). The Empirical Relationship between Trading Volumes \& Stock Return Volatility in Indian Stock Market. European Journal of Economics, Finance and Administrative Sciences, 24, 59-77.

Pena, J. I. (1995). Daily seasonalities and stock market reforms in Spain. Applied Financial Economics, 5(6), 419-423. http://dx.doi.org/10.1080/758538601

Rogalski, R. J. (1984). New Findings Regarding Day-of-the-Week Returns over Trading and Non-Trading Periods: A Note. The Journal of Finance, 39(5), 1603-1614. http://dx.doi.org/10.1111/j.1540-6261.1984.tb04927.x

Santesmases, M. (1986). An investigation of the Spanish stock market seasonalities. Journal of Business Finance \& Accounting, 13(2), 267-276. http://dx.doi.org/10.1111/j.1468-5957.1986.tb00096.x

Smirlock, M., \& Starks, L. (1986). Day-of-the-week and intraday effects in stock returns. Journal of Financial Economics, 17(1), 197-210. http://dx.doi.org/10.1016/0304-405X(86)90011-5

Snedecor, G., \& Cochran, W. (1976). Statistical methods. Ames: Iowa Press. PMid:6206

Sutheebanjard, P., \& Premchaiswadi, W. (2010). Analysis of calendar effects: Day-of-the-week effect on the stock exchange of Thailand (SET). International Journal of Trade, Economics and Finance, 1(1), 57-62.

Theobald, M., \& Price, V. (2012). Seasonality estimation in thin markets. The Journal of Finance, 39(2), 377-392. http://dx.doi.org/10.1111/j.1540-6261.1984.tb02315.x

Ulussever, T., GURAN YUMUSAK, I., \& Kar, M. (2011). The day-of-the-week effect in the 
Saudi stock exchange: A non-linear GARCH Analysis. Journal of Economic and Social Studies, 1(1), 9-23.

Wachtel, S. B. (1942). Certain observations on seasonal movements in stock prices. The Journal of Business of the University of Chicago, 15(2), 184-193. http://dx.doi.org/10.1086/232617

Worthington, A. C. (2010). The decline of calendar seasonality in the Australian stock exchange, 1958-2005. Annals of Finance, 6(3), 421-433. http://dx.doi.org/10.1007/s10436-008-0111-9

Table 1. Basic statistics of returns

\begin{tabular}{|c|c|c|c|c|c|}
\hline & Monday & Tuesday & Wednesday & Thursday & Friday \\
\hline \multicolumn{6}{|l|}{ Mean } \\
\hline Indonesia & -0.001506 & -0.000434 & 0.002308 & 0.000173 & 0.000860 \\
\hline Malaysia & -0.000897 & -0.000152 & 0.000665 & 0.000319 & 0.000317 \\
\hline Philippines & -0.000678 & -0.001365 & 0.002142 & 0.000882 & -0.000134 \\
\hline Singapore & -0.001024 & -0.000845 & 0.001108 & -0.000297 & -0.000377 \\
\hline Thailand & -0.001167 & 0.000248 & 0.000731 & -0.000128 & 0.000848 \\
\hline \multicolumn{6}{|l|}{ Median } \\
\hline Indonesia & -0.000097 & 0 & 0.002926 & 0.000600 & 0.0004352 \\
\hline Malaysia & 0 & 0 & 0.000864 & 0.000197 & 0 \\
\hline Philippines & 0 & -0.000728 & 0.001983 & 0.000389 & 0 \\
\hline Singapore & 0 & -0.000182 & 0.001506 & -0.000234 & 0 \\
\hline Thailand & 0 & 0 & 0.002096 & 0.000698 & 0.001192 \\
\hline \multicolumn{6}{|l|}{ Maximum } \\
\hline Indonesia & 0.073628 & 0.062383 & 0.076234 & 0.052681 & 0.068192 \\
\hline Malaysia & 0.040551 & 0.028005 & 0.026538 & 0.028701 & 0.033750 \\
\hline Philippines & 0.049837 & 0.070560 & 0.043754 & 0.046251 & 0.045872 \\
\hline Singapore & 0.063639 & 0.055912 & 0.049232 & 0.075305 & 0.056203 \\
\hline Thailand & 0.075487 & 0.052919 & 0.032799 & 0.060994 & 0.041853 \\
\hline \multicolumn{6}{|l|}{ Minimum } \\
\hline Indonesia & -0.105675 & -0.080103 & -0.0109539 & -0.092997 & -0.071555 \\
\hline Malaysia & -0.099785 & -0.039179 & -0.035180 & -0.031940 & -0.036807 \\
\hline Philippines & -0.0130887 & -0.056743 & -0.049229 & -0.053232 & -0.086981 \\
\hline Singapore & -0.062165 & -0.042293 & -0.068388 & -.0 .053965 & -0.086960 \\
\hline Thailand & -0.110902 & -0.042844 & -0.071271 & -0.054430 & -0.100994 \\
\hline
\end{tabular}

Standard Deviation 


\begin{tabular}{|c|c|c|c|c|c|}
\hline Indonesia & 0.018976 & 0.016591 & 0.017791 & 0.016336 & 0.014639 \\
\hline Malaysia & 0.011135 & 0.008245 & 0.007880 & 0.008568 & 0.008458 \\
\hline Philippines & 0.016691 & 0.014716 & 0.012370 & 0.013539 & 0.013838 \\
\hline Singapore & 0.017644 & 0.013336 & 0.014492 & 0.015295 & 0.014100 \\
\hline Thailand & 0.019354 & 0.015175 & 0.013410 & 0.014647 & 0.014276 \\
\hline
\end{tabular}

\section{Skewness}

\begin{tabular}{|c|c|c|c|c|c|}
\hline Indonesia & -0.0568902 & -0.290924 & -0.895448 & -1.162683 & -0.464237 \\
\hline Malaysia & -3.178384 & -0.456030 & -0.520078 & -0.330540 & -0.184831 \\
\hline Philippines & -2.558812 & 0.238628 & -0.141149 & -0.574296 & -0.935930 \\
\hline Singapore & 0.020217 & 0.282502 & -0.375711 & 0.626146 & -1.294918 \\
\hline Thailand & -0.812219 & 0.276306 & -1.060338 & -0.024374 & -1.879603 \\
\hline
\end{tabular}

\section{kurtosis}

\begin{tabular}{|c|c|c|c|c|c|}
\hline Indonesia & 6.780524 & 3.648543 & 9.451008 & 6.039140 & 5.837154 \\
\hline Malaysia & 30.128948 & 3.676943 & 3.351936 & 2.200489 & 3.973636 \\
\hline Philippines & 17.893892 & 4.868837 & 2.158542 & 2.367858 & 7.710789 \\
\hline Singapore & 1.916244 & 2.073026 & 3.843113 & 4.210506 & 10.754751 \\
\hline Thailand & 6.19498 & 1.422250 & 3.652336 & 3.372682 & 13.610629 \\
\hline \multicolumn{6}{|l|}{ Variance } \\
\hline Indonesia & 0.000360 & 0.000275 & 0.000317 & 0.000267 & 0.000214 \\
\hline Malaysia & 0.000124 & 0.000068 & 0.000062 & 0.000073 & 0.000072 \\
\hline Philippines & 0.000279 & 0.000217 & 0.000153 & 0.000183 & 0.000191 \\
\hline Singapore & 0.000311 & 0.000178 & 0.000210 & 0.000234 & 0.000199 \\
\hline Thailand & 0.000375 & 0.000230 & 0.000180 & 0.000215 & 0.000204 \\
\hline \multicolumn{6}{|c|}{ Coefficient of Variation } \\
\hline Indonesia & -1259.94094 & -3819.90647 & 770.677314 & 9451.018148 & 1701.459505 \\
\hline Malaysia & -1241.098953 & -5441.92199 & 1184.489460 & 2685.491843 & 2671.388063 \\
\hline Philippines & -2460.941227 & -1078.05209 & 577.443001 & 1534.280927 & -10291.50842 \\
\hline Singapore & -1723.186503 & -1578.68767 & 1307.890448 & -5147.52037 & -3735.476078 \\
\hline Thailand & -1658.617323 & 6114.57897 & 1834.646440 & -11441.4353 & 1683.623564 \\
\hline
\end{tabular}




\section{Macrothink}

Asian Journal of Finance \& Accounting ISSN 1946-052X 2013, Vol. 5, No. 1

Table 2. Summary of Maximum/Minimum Returns/Standard Deviations of five stock markets for the Period December 31, 2008- December 31, 2011

\begin{tabular}{|c|c|c|c|c|}
\hline Country/Index & $\begin{array}{c}\text { Max } \\
\text { (Standard deviation) } \\
\text { Mean }\end{array}$ & Occurrence & $\begin{array}{c}\text { Min } \\
\text { (Standard deviation) } \\
\text { Mean }\end{array}$ & Day of \\
Occurrence \\
\hline $\begin{array}{c}\text { Jakarta Composite } \\
\text { (Indonesia) }\end{array}$ & 0.002308 & Wednesday & -0.001506 & Monday \\
\hline Kuala Lumpur Composite & 0.018976 & Monday & 0.014639 & Friday \\
\hline (Malaysia) & 0.000665 & Wednesday & -0.000897 & Monday \\
Manila Composite & 0.011135 & Monday & 0.007880 & Wednesday \\
\hline (Philippines) & 0.002142 & Wednesday & -0.001365 & Tuesday \\
Straits Times & 0.016691 & Thursday & 0.012370 & Wednesday \\
\hline (Singapore) & 0.001108 & Wednesday & -0.001024 & Monday \\
SET & 0.017644 & Monday & 0.013336 & Tuesday \\
\hline (Thailand) & 0.000848 & Friday & -0.001167 & Monday \\
\hline
\end{tabular}

Table 3. Annual Closing Index Values and two important dates

\begin{tabular}{|c|c|c|c|c|c|}
\hline End of Year & (Indonesia) & (Malaysia) & (Philippines) & (Singapore) & (Thailand) \\
\hline $\mathbf{2 0 0 7}$ & 2745.83 & 1445.03 & 3621.6 & 3482.3 & 858.1 \\
\hline OCT 2008 & 1111.39 & 832.44 & 1704.41 & 1600.28 & 384.15 \\
\hline $\mathbf{2 0 0 8}$ & 1355.41 & 876.75 & 1872.85 & 1761.56 & 449.96 \\
\hline $\mathbf{2 0 0 9}$ & 2534.36 & 1272.78 & 3052.68 & 2897.62 & 734.54 \\
\hline $\mathbf{2 0 1 0}$ & 3703.51 & 1518.91 & 4201.14 & 3190.04 & 1032.76 \\
\hline JULY 2011 & 4193.44 & 1558.01 & 4550.53 & 3215.27 & 1144.14 \\
\hline $\mathbf{2 0 1 1}$ & 3821.99 & 1530.73 & 4371.96 & 2646.35 & 1025.32 \\
\hline
\end{tabular}




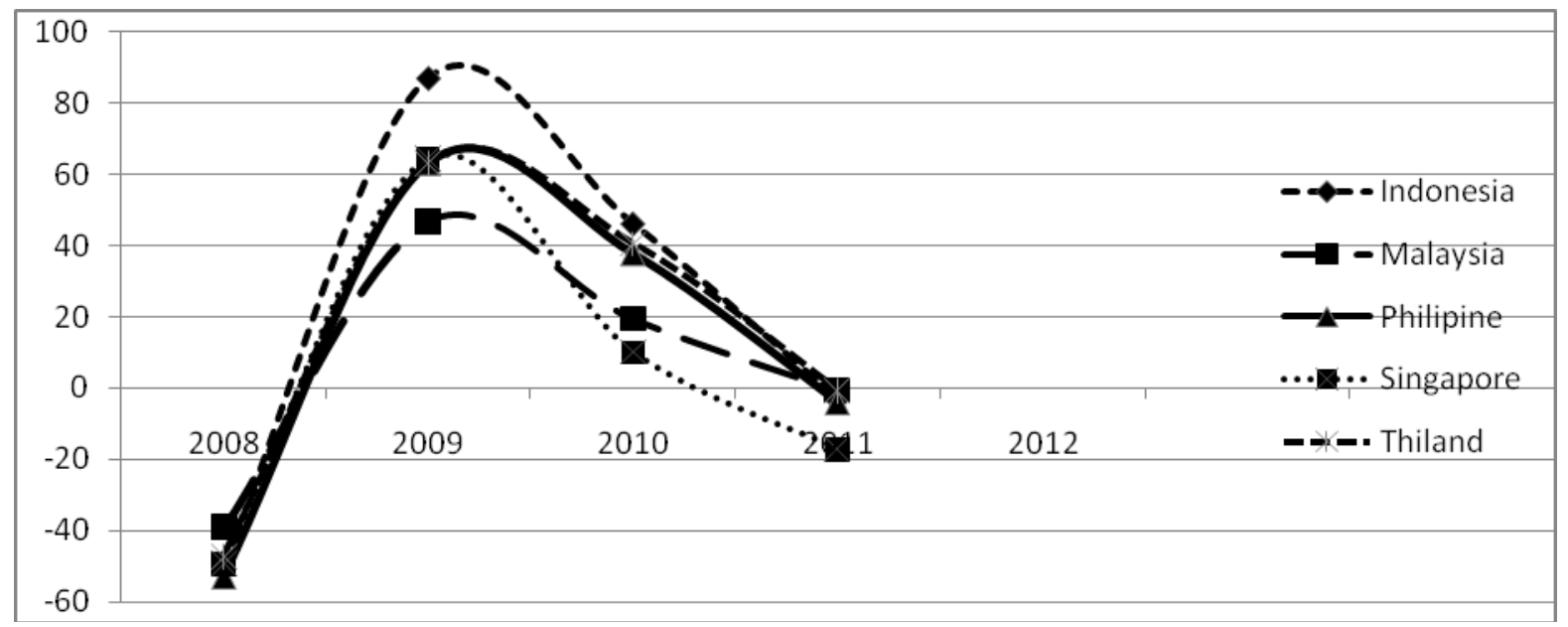

Figure 1. Percent Changes in yearly Returns in five selected Southeast stock Markets

Table 4. Correlation coefficient, Regression Results

\begin{tabular}{|c|c|c|c|c|c|}
\hline Correlation matrix & $\begin{array}{c}\text { Jakarta } \\
\text { Composite } \\
\text { (Indonesia) }\end{array}$ & $\begin{array}{c}\text { Kuala } \\
\text { Lumpur } \\
\text { Composite } \\
\text { (Malaysia) }\end{array}$ & $\begin{array}{c}\text { Manila } \\
\text { Composite } \\
\text { (Philippines) }\end{array}$ & $\begin{array}{c}\text { Straits } \\
\text { Times } \\
\text { (Singapore) }\end{array}$ & $\begin{array}{c}\text { SET } \\
\text { (Thailand) }\end{array}$ \\
\hline $\begin{array}{c}\text { Jakarta } \\
\text { Composite (Indonesia) }\end{array}$ & 1 & 0.553046 & 0.469881 & 0.628018 & 0.543608 \\
\hline $\begin{array}{c}\text { Kuala Lumpur } \\
\text { Composite (Malaysia) }\end{array}$ & 0.553046 & 1 & 0.476428 & 0.564179 & 0.481748 \\
\hline $\begin{array}{c}\text { Manila } \\
\text { Composite (Philippines) }\end{array}$ & 0.469881 & 0.476428 & 1 & 0.402785 & 0.425613 \\
\hline $\begin{array}{c}\text { Straits Times } \\
\text { (Singapore) }\end{array}$ & 0.628018 & 0.564179 & 0.402785 & & 1 \\
\hline SET & 0.543608 & 0.481748 & 0.425613 & 0.605116 & 1 \\
\hline
\end{tabular}

Table 5. The result of Kruskal-Wallis test (equality of means)

\begin{tabular}{|c|c|c|c|c|c|}
\hline Index/country & $\begin{array}{c}\text { Jakarta Composite } \\
\text { (Indonesia) }\end{array}$ & $\begin{array}{c}\text { Kuala Lumpur } \\
\text { Composite (Malaysia) }\end{array}$ & $\begin{array}{c}\text { Manila Composite } \\
\text { (Philippines) }\end{array}$ & $\begin{array}{c}\text { Straits Times } \\
\text { (Singapore) }\end{array}$ & $\begin{array}{c}\text { SET } \\
\text { (Thailand) }\end{array}$ \\
\hline Chi-square & ${ }^{*} 10.4711$ & 2.4123 & 9.3381 & 7.4712 & 8.8693 \\
\hline p-value & 0.0332 & 0.6604 & 0.0532 & 0.1130 & 0.0644 \\
\hline
\end{tabular}

Note: $*$ denote significant at 5\% level. 
Table 6. Results of equality of variance test across day of the week for the period 2008- 2012

\begin{tabular}{|c|c|c|c|c|}
\hline \multirow{2}{*}{\begin{tabular}{c} 
Countries/Index \\
\cline { 2 - 5 }
\end{tabular}} & Statistics & P-Value & Statistics & P-Value \\
\cline { 2 - 5 } $\begin{array}{c}\text { Jakarta } \\
\text { Composite (Indonesia) }\end{array}$ & 1.6968 & 0.1484 & 16.480 & 0.0024 \\
\hline $\begin{array}{c}\text { Kuala Lumpur } \\
\text { Composite (Malaysia) }\end{array}$ & 1.1307 & & & \\
\hline $\begin{array}{c}\text { Manila } \\
\text { Composite (Philippines) }\end{array}$ & $8.1602^{*}$ & 0.3405 & 32.9826 & 0.0000 \\
\hline $\begin{array}{c}\text { Straits Times } \\
\text { (Singapore) }\end{array}$ & $3.9776^{*}$ & 0.0000 & 98.4733 & 0.0000 \\
\hline SET & & & & \\
(Thailand) & $4.4783^{*}$ & 0.0033 & 20.5923 & 0.0004 \\
\hline
\end{tabular}

Note: *denote significant at 5\% level. 